
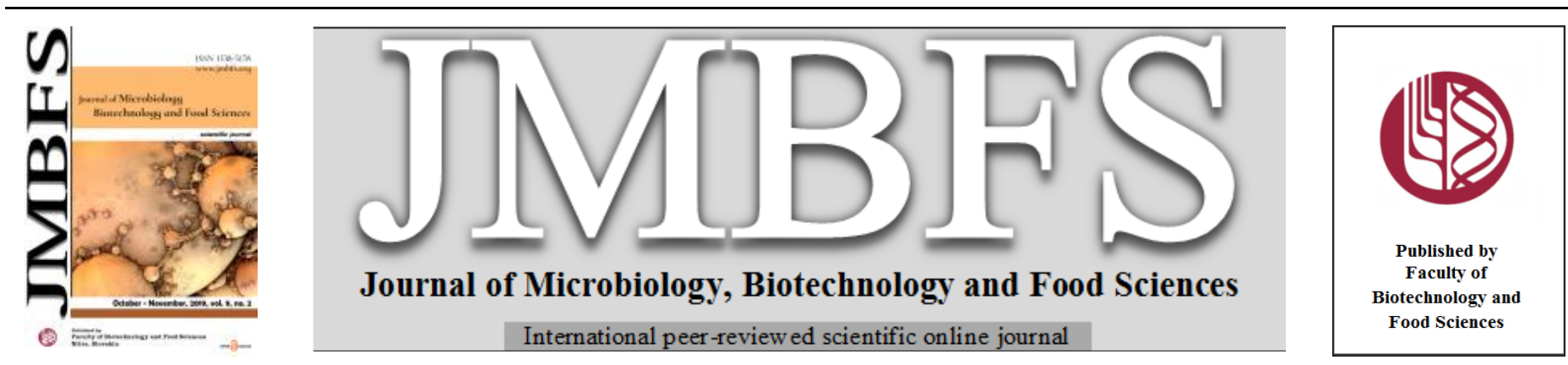

\title{
A COMPARATIVE STUDY ON CHARACTERISTICS OF PECTINS FROM VARIOUS FRUIT PEEL WASTES EXTRACTED USING ACID AND MICROBIAL ENZYMES
}

\author{
Katherine Ann T. Castillo-Israel*1, Juliecar Faith R. Amian ${ }^{I}$, Zserina Jhoanne S. Garibay ${ }^{I}$, Vince Ellison B. Leyezal, Ave Jee T. \\ Sarte $^{l}$
}

Address(es): Dr. Katherine Ann T. Castillo-Israel,

${ }^{1}$ Institute of Food Science and Technology, College of Agriculture and Food Science, University of the Philippines Los Banos. College, Laguna, Philippines.

*Corresponding author: kcisrael@up.edu.ph

doi: 10.15414/jmbfs.2019.9.2.216-221

\section{ARTICLE INFO}

Received 28. 12. 2018

Revised 28. 3. 2019

Accepted 1. 4. 2019

Published 1. 10. 2019

Regular article

OPEN OACCESS

\begin{abstract}
The potential of microbial enzyme-aided extraction of pectin from fruit processing wastes was evaluated to assess its possible use as an environment friendly alternative to acid extraction methods. Peel wastes from yellow passion fruit (Passiflora edulis Slims var. flavicarpa), 'Saba' banana (Musa 'saba' [Musa acuminata x Musa balbisiana]), 'Carabao'mango (Mangifera indica L. cv. 'Carabao') and soursop 'guyabano'(Annona muricata) were extracted of pectin using different microbial enzymes namely cellulase, xylanase, pectinase and $\alpha$-amylase. The efficiency of the enzymatic extraction as well as pectin quality were compared with acid extraction. Generally, high yields were obtained using cellulase and $\alpha$-amylase. The yields from enzymatic extractions were however significantly lower compared with the acid extraction. Highest yields were obtained from 'Carabao' mango peels. The chemical properties of the pectins extracted from the fruit peels highly varied depending on the fruit and the extraction method. Pectin from yellow passion fruit peels was classified as low methoxyl (LM) based on the degree of esterification values while the rest of the pectins were classified as high methoxyl(HM). Analyses of the anhydrouronic acid (AUA) content showed that 'Carabao' mango peel pectins had high purity while the pectins from the other fruits had low purities. Equivalent weights of the fruit peel pectins from microbial extraction were significantly higher than that from acid extraction and from commercial citrus peel pectin. 'Carabao'mango, 'Saba' banana, yellow passion fruit and soursop 'guyabano' peels are potential sources of pectin for food applications. Acid extraction was found to be more efficient compared with microbial enzyme-aided extraction.
\end{abstract}

Keywords: pectin, cellulase, xylanase, pectinase, $\alpha$-amylase, acid extraction, 'Saba' peel pectin

\section{INTRODUCTION}

The Philippines is known for its high tropical fruit production. Most of the fruits are consumed fresh, while other portions go to the export market and to processing. For banana, $17 \%$ of production goes to processing while for pineapple, 37\% (Espino and Espino, 2015). Fruit processing generates huge amounts of wastes in the form of peels and inedible parts. In fact, fruit wastes are considered as one of the main municipal solid wastes and their disposal have become an environmental issue. These wastes, if mismanaged in landfills, will result to air pollution through their methane and carbon dioxide emissions. Opting for incineration will likewise contribute to air pollution (Deng et al., 2012).

Pectin is one component of fruit wastes which has industrial applications. Aside from its wide use as an additive in processed foods and as edible film (Espitia $e t$ al., 2014), it is also gaining popularity in biomedical applications such as drug delivery, gene delivery, wound healing and tissue engineering due to its simple and cytocompatible gelling mechanism (Munarin et al., 2013). Presently, commercial pectins are only produced from citrus (lime, lemon, orange, and grapefruit) peels and apple pomace, which are by-products of the juice industry in western countries (Yapo and Koffi, 2014). Dry citrus peel (15\%-30\% pectin) and apple pomace $(10 \%-15 \%$ pectin) are considered as good sources.

Pectin has been extracted from fruit peels using various methods, acid extraction being the conventional method (Yapo, 2009). However, there are certain drawbacks with the use of acids as they may cause environmental problems by producing hazardous contaminants that must be treated (Min et al., 2011). Also, the harsh condition in acid extraction causes damage to pectin structure. Efforts to reduce use of harmful chemicals are recently being done in the industry. The use of enzyme-aided extraction methods are being studied extensively as substitute to chemical methods because aside from being eco-friendly, they also require mild conditions of $\mathrm{pH}$ and temperature. For the extraction process, temperature and $\mathrm{pH}$ applied is based on the optimum activity of the enzymes used so as to avoid damaging and denaturing the enzymes. The process is usually carried out at $\mathrm{pH}$ between 3-5 and temperatures of around $50^{\circ} \mathrm{C}$ depending on the enzyme's optimum. This is more advantageous in terms of economy and environmental impact. Moreover, since the $\mathrm{pH}$ of the extraction process is much higher than in that of traditional acid-based approach, there is no need for waste neutralization (Dominiak et al., 2014). Recent studies on enzyme-hydrolytic technology seem more environmentally safe and more effective in pectin yield (Ptichkina et al., 2007). Enzyme-aided extraction of pectin have been conducted using polygalacturonase (Contreras-Esquivel et al., 2006), cellulase and $\alpha$ amylase (Cui and Chang, 2014), $\alpha$-amylase and neutrase (Qiu et al. 2010), cellulase (Fissore et al., 2013), Viscozyme L (Lim et al., 2012), Celluclast (Liew et al., 2015) and protease (Zykwinska et al., 2008).

Particular applications of pectin are dependent on their chemical nature. Characteristics of pectin extracted using various methods were also found to be affected by the extraction method. Direct boiling in acid, the conventional method, causes degradation of pectin due to prolonged heating (Srivastava and Malviya, 2011). The use of enzymes for pectin extraction however, leads to varied properties of pectins since pectic substances undergo changes, such as demethylation, deacetylation and shortening of the polymer chain (Dominiak et al., 2014). Enzymatic extraction method was found to have greater capability of producing high methoxyl pectin (Liew et al., 2015). Manipulation of degree of esterification (DE) can also be possible by extraction using enzymes from Aspergillus awamori (Ptichkina et al., 2007). Thus the influence of the extraction method on the characteristics of the pectin extracted is an important consideration in the choice of method.

In this study, microbial enzymes namely cellulase, xylanase, pectinase and $\alpha$ amylase were screened for efficiency of pectin extraction from various fruit peel wastes to determine their possible potential as an eco-friendly option of method for pectin extraction. Pectin characterization was likewise conducted to assess their potential for food applications. 


\section{MATERIAL AND METHODS}

\section{Raw Materials}

Peel wastes of yellow passion fruit, 'Saba' banana, 'Carabao' mango, and soursop 'guyabano' were obtained from fruit processing plants in Los Banos, Laguna, Philippines. From the fruit processing plants, the following are the maturities of the fruits used: yellow passion fruit- ripe, 'Saba' banana-unripe, 'Carabao' mango-ripe, soursop 'guyabano'-ripe. The peels were sliced thinly and dried in an oven dryer at $60^{\circ} \mathrm{C}$ for $24 \mathrm{~h}$. The dried peels were then ground to pass through a 'no.80' mesh sieve. Commercially available preparations of crude microbial enzymes namely cellulase, xylanase, pectinase and $\alpha$-amylase were obtained from the National Institute of Biotechnology and Molecular Biology (BIOTECH), University of the Philippines Los Banos. Each of the enzymes had activity of $500 \mathrm{U} / \mathrm{mg}$.

\section{Swelling of sample prior to extraction}

Approximately $25 \mathrm{~g}$ of powdered peels were added with $175 \mathrm{ml}$ distilled water and were allowed to swell under room temperature for at least $24 \mathrm{~h}$.

\section{Extraction of Pectin}

\section{Enzymatic extraction}

Four different microbial enzymes were used namely cellulase, xylanase, pectinase and $\alpha$-amylase. The enzymes were all diluted to a final activity of 55.5 $\mathrm{U} / \mathrm{mg}$ from the initial $500 \mathrm{U} / \mathrm{mg}$. To the swollen peel powder, an equal volume of the diluted enzyme was added. The mixture was heated and maintained at a temperature range of $45 \pm 5^{\circ} \mathrm{C}$ (pre-determined optimum temperature of the enzymes) for $3 \mathrm{~h}$ with constant stirring maintained at $\mathrm{pH}$ 4.4. The mixture was then filtered using two layers of cheesecloth. The filtrate was heated to $55^{\circ} \mathrm{C}$ for 1 $\mathrm{h}$ to deactivate the enzyme. After which, precipitation of pectin was carried out by adding absolute ethanol at an amount equal to twice the volume of the filtrate, and then stirred for $1 \mathrm{~h}$. The precipitated pectin was filtered using a pre-weighed miracloth, oven-dried at $60^{\circ} \mathrm{C}$ for $24 \mathrm{~h}$, then weighed. Pectin yield was calculated based on the initial weight of the peel powders using the formula:

$$
\% \text { Yield }=\frac{\text { weight of dried pectin, } g}{\text { weight of sample, } g} \times 100
$$

\section{Acid extraction}

Acid extraction using $\mathrm{HCl}$ was also carried out to compare this method with the enzymatic extraction. The method by Castillo-Israel et al. (2015) was employed. Peel powders were added to $0.50 \mathrm{~N} \mathrm{HCl}, \mathrm{pH} 1.5$ then heated with continuous stirring at $90 \pm 5^{\circ} \mathrm{C}$ in a stirring hot plate for $3 \mathrm{~h}$. The solution was then cooled and filtered through two layers cheesecloth. The filtrate was collected then added with twice its volume of absolute ethanol and stirred for $1 \mathrm{~h}$. The precipitates were filtered through a pre-weighed miracloth. The residue was oven dried for 24 $\mathrm{h}$ at $55^{\circ} \mathrm{C}$ and then weighed. Pectin yield was calculated based on the initial weight of the peel powders using the same formula.

\section{Chemical characterization of extracted pectin}

Standard methods by Owens et al. (1952) were employed in the following analyses.

\section{Equivalent weight}

About $0.5 \mathrm{~g}$ dried pectin sample was added with $5 \mathrm{~mL}$ absolute ethanol. Then, 1.0 $\mathrm{g}$ of $\mathrm{NaCl}$ was added together with $100.0 \mathrm{~mL}$ of $\mathrm{CO}_{2}$-free distilled water, and 6 drops of phenol red indicator. The solution was stirred for at least $10 \mathrm{~min}$ or until the dried pectin sample dissolves. It was then titrated with $0.1 \mathrm{~N}$ standard $\mathrm{NaOH}$ until $\mathrm{pH}$ 7.5. Equivalent weight of the pectin was calculated using the formula:

$$
\text { Equivalent weight }(\mathrm{EW}), \frac{\mathrm{g}}{\mathrm{mol}}=\frac{\text { weight of sample, } \mathrm{g} \times 1000}{\text { volume of } \mathrm{NaOH}, \mathrm{mL} \times \mathrm{N} \mathrm{NaOH}}
$$

\section{Methoxyl content}

Methoxyl content (MC) was carried out by initially adding $25 \mathrm{~mL}$ of $0.25 \mathrm{~N}$ $\mathrm{NaOH}$ to $0.5 \mathrm{~g}$ dried pectin sample then stirred for at least 10 min or until the dried pectin sample dissolves. The solution was covered and let stand for $30 \mathrm{~min}$ at room temperature. After standing, $25 \mathrm{~mL}$ of $0.25 \mathrm{~N} \mathrm{HCl}$ was added, and then titrated with $0.1 \mathrm{~N}$ standard $\mathrm{NaOH}$ until $\mathrm{pH}$ 7.5. Methoxyl content was calculated using the formula:

$$
\% \text { Methoxyl content }(M C)=\frac{\text { Volume of } \mathrm{NaOH}, \mathrm{mL} \times \mathrm{N} \mathrm{NaOH} \times 3.1}{\text { weight of sample, } \mathrm{g}}
$$

\section{Anhydrouronic acid}

Percent anhydrouronic acid (AUA) was calculated from the previously calculated equivalent weight and methoxyl content of the pectin sample using the formula:

$$
\begin{array}{r}
\% \text { Anhydrouronic acid }(A U A) \\
\qquad=\left(\frac{176 \times 0.1 z \times 100}{\text { ave.wt.of samples, } g \times 1000}\right) \\
+\left(\frac{176 \times 0.1 y \times 100}{\text { ave.wt. of samples, } g \times 1000}\right)
\end{array}
$$

where:

$$
\begin{aligned}
& \mathrm{z}=\text { Volume of } \mathrm{NaOH} \text { used in } \mathrm{EW}, \mathrm{mL} \\
& \mathrm{y}=\text { Volume of } \mathrm{NaOH} \text { used in } \mathrm{MC}, \mathrm{mL}
\end{aligned}
$$

\section{Degree of esterification}

The DE is defined as a ratio of esterified galacturonic acid groups to the galacturonic acid groups present (Van Buren, 1991).The degree of esterification was also calculated using prior calculations of the MC and AUA using the formula:

$$
\% \text { Degree of esterification }(D E)=\left(\frac{176 \times \% M C \times 100}{31 \times A U A}\right)
$$

\section{Scanning Electron Microscopy (SEM)}

Pectin samples were observed for their morphology under a scanning electron microscope (Phenom XL) at 5000x magnification.

\section{Statistical Analysis}

Data were analyzed using SAS software version 9. ANOVA was performed to determine significant differences followed by Tukey's HSD at $95 \%$ confidence level. Statistical analyses were done per fruit peel group.

\section{RESULTS AND DISCUSSION}

\section{Pectin yield from various fruit peels using acid and enzyme extraction}

The different microbial enzymes (cellulase, xylanase, pectinase and $\alpha$-amylase) were compared with hydrochloric acid as agents for pectin extraction from various fruit peel wastes. Extracted pectins appeared to be cream to brown in color based on visual observation (Figure 1). The lightest colored pectin was obtained from 'Saba' banana peels while the darkest was from soursop 'guyabano.' Pectin yield was shown to be significantly affected by the extraction method (Figure 2). In yellow passion fruit, 'saba' banana and 'Carabao'mango peels, significantly higher yield (21-33\%) was obtained from acid extraction compared with the enzymatic methods (2-13\%). In soursop 'guyabano' peels however, acid extraction yield was close to those of enzymatic extraction (5-9\%). Extraction method of pectin involves two main steps, hydrolysis of the complex pectin substance and its precipitation. Acid extraction involves hydrolysis step done at a much higher temperature of about $70-90^{\circ} \mathrm{C}$ and a relatively lower $\mathrm{pH}$ range of 1.5 to 2.5 (Rolin et al., 1998). High temperature is needed to soften the carbohydrate polymer structure (Liew et al., 2015). Pectins are found in the middle lamellae and primary cell wall of fruit peels together with celluloses and hemicelluloses (Thakur et al., 2014). The drastic conditions of high temperature and low $\mathrm{pH}$ causes breakdown of hydrogen bonds which are involved between pectin and the cell wall which results to the faster rate of pectin extraction. Increased hydrolysis of celluloses and hemicelluloses in the cell wall results to increased amounts of pectins released. Enzymes act by deconstructing plant cell wall and eventually isolate pectin (Panouille et al., 2006). However, the milder conditions employed in enzymatic extraction which are $45 \pm 5^{\circ} \mathrm{C}$ and $\mathrm{pH} 4.4$ resulted to lesser pectin yield due to incomplete hydrolysis of celluloses and hemicelluloses in the cell wall. Also, there is slower interaction of enzymes with the cellulose and galactan side chains of pectins (Liew et al., 2015). In addition, enzymes are highly specific, each hydrolyzing only a specific polysaccharide component attached to the pectin molecule, which leads to lesser pectin yield unlike in acid extraction where there is no specificity and the action is random hydrolysis of glycosidic bonds.

In terms of the efficiency of the different enzymes in pectin extraction, no significant differences among the four enzymes were observed in yellow passion fruit, 'Carabao' mango and soursop 'guyabano' peels. On the other hand, for 'Saba' banana peels, cellulase has shown to be significantly efficient among the enzymes as shown by the highest pectin yield obtained, though the value is relatively low (6.18\%) compared with the other enzymatic extractions (Figure 1). Cellulase act by hydrolyzing cellulose glycosidic linkages. Several studies have reported the successful use of cellulase in pectin extraction such as in pumpkin (Cui and Chang, 2014), butternut (Fissore et al., 2013) and chicory roots (Zykwinska et al., 2008). A cellulase preparation, Celluclast 1.5L, has also been applied in rapeseed cake (Jeong et al., 2014), passion fruit (Liew et al., 2015) 
and kiwifruit (Yuliarti et al., 2011). Since the specificity of cellulase is cellulose, which comprise majority of the polysaccharides in the cell wall (Chen, 2014), it was the most efficient among the four enzymes to deconstruct the cell wall and expose the pectins in 'Saba' banana. Insignificant differences among the enzymes were observed with yellow passion fruit, 'Carabao' mango and soursop 'guyabano'.

\section{Equivalent weights of the extracted pectins}

In Figure 3, equivalent weights of pectin extracted from yellow passion fruit, 'Saba' banana and 'Carabao'mango peels using enzymes range from 2000-4000 $\mathrm{g} \mathrm{mol}^{-1}$ while those from soursop 'guyabano' were higher, reaching up to $8400 \mathrm{~g}$ $\mathrm{mol}^{-1}$. Comparing the enzymatic methods with acid extraction, significantly lower equivalent weights were obtained in acid extraction for yellow passion fruit, 'Carabao' mango and soursop 'guyabano' peels (around 600-900 g mol ${ }^{-1}$ ) Comparing the different enzymes' effects on equivalent weight, cellulase produced the highest equivalent weight of pectin from 'Saba' banana peels, xylanase for yellow passion fruit peels and $\alpha$-amylase for 'Carabao' mango and soursop 'guyabano'

Raj et al.(2012) mentioned that detection of a large quantity of pectin in a fruit alone is not in itself enough to qualify that fruit as a source of commercial pectin The ability of pectins to form gel depends on the molecular size and degree of esterification (DE). Equivalent weights of the pectins are important indicators of gelling property. Higher equivalent weight indicates that an extracted pectin has a higher capability to form gel (Vaclavik and Christian, 2008). Results show that lower molecular weight pectins were obtained from extraction with $\mathrm{HC}$ compared with all of the enzymatic extractions from the four fruit peels. This can be attributed to the low $\mathrm{pH}$ and high temperature employed in acid extraction which destroys the pectin structure by demethylation and hydrolysis, shortening the pectin fragments. Yujaroen et al.(2008) had reported that the glycosidic bond can undergo hydrolysis reaction at the right conditions $\left(80^{\circ} \mathrm{C}\right.$ at $\mathrm{pH} 2$, or at $\mathrm{pH} 8$ for two hours). Even though a low $\mathrm{pH}$ is necessary to improve the yield, the strong acid solution could lead to smaller pectin particles owing to partia hydrolysis (Shaha et al., 2013). In addition, acid extraction needs longer time, thus, there is a risk of thermal degradation for the thermolabile materials (Seixas et al., 2014).

Comparing the different enzymes' effects on equivalent weight, cellulase produced the highest equivalent weight of pectin from 'Saba' banana peels, xylanase for yellow passion fruit peels and $\alpha$-amylase for 'Carabao'mango and soursop 'guyabano'. Main polysaccharides of primary walls are cellulose, hemicellulose, and pectin. Cellulose accounts for 15-30\% dry weight of the primary cell wall. Pectin accounts for about $30 \%$ of polysaccharide of the primary cell wall, located between the cellulose microfilaments of the cell wall (Chen, 2014). Cellulase is an efficient enzyme for pectin extraction because it acts on cellulose by hydrolyzing glycosidic linkages and breaking the cellulose fibrils. This breakdown of cellulose structure results to the release of pectins from the primary cell wall. Liew et al. (2015) also reported successful extraction of pectin from passion fruit peels using Celluclast, an enzyme preparation containing cellulase. Cellulase with protease was also shown to efficiently extract pectin from chickory and cauliflower by-products (Panouille et al., 2006).

$\alpha$-amylase on the other hand, aids in extracting pectin by degrading the starches that may contaminate the pectins after extraction. Starch is another glucose polysaccharide abundant in plants. Though not part of the cell wall, they may cause difficulty in extracting pectin due to their solubility in water. Since the specificity of $\alpha$-amylase is only for starches, the pectin extracted from 'Carabao' mango and soursop 'guyabano' were not degraded, thus resulting to high equivalent weights. Some pectin extraction studies conducted also employed $\alpha$ amylase (Qiu et al., 2010; Cui and Chang, 2014).

\section{Methoxyl Content(MC) and Degree of Esterification (DE) of the extracted pectins}

For methoxyl content of yellow passion fruit peels (Figure 4), high methoxy (HM) pectins (\%methoxyl content $>7.0 \%$ ) were obtained only from $\mathrm{HCl}$ and cellulase. Low methoxyl (LM) were obtained from 'Saba' banana and soursop 'guyabano' peels. For 'Carabao' mango, HM were obtained from all enzymes while $\mathrm{LM}$ came out from $\mathrm{HCl}$ extraction. Based on degree of esterification (Figure 5), pectin from yellow passion fruit can be generally classified as $\mathrm{LM}(<50 \% \mathrm{DE})$ except those extracted using cellulase and $\mathrm{HCl}$. Values for all extraction methods were not significantly different. For 'Saba' banana peels, all can be classified as HM ( $>50 \% \mathrm{DE})$ though significantly lower amounts were obtained from xylanase. 'Carabao' mango peel pectin also fall under HM for the enzymatic extraction but much lower DE was obtained from $\mathrm{HCl}$ extraction. Soursop 'guyabano' peel pectins were also classified as HM but significantly lower values were obtained from xylanase and $\mathrm{HCl}$ extraction.

The presence of methyl groups is a very important feature of pectic polymers which affect their functionalities. Pectin producers traditionally divide pectin polymers into high and low methoxyl pectins (HM and LM pectins). This is measured in two ways: degree of esterification (DE) and methoxyl content. The ratio of esterified galacturonic acid groups to total galacturonic acid groups is termed as the DE. During tissue development, pectin might be formed initially in a highly esterified form, but undergoes some deesterification after they have been inserted into the cell wall or middle lamella. DEs may be dependent on species, tissue, and maturity. In general, naturally present tissue pectins range from 60 to 90\% DE (Raj et al., 2012). In terms of DE, the boundary level between the two types is $50 \%$, which means that if greater than $50 \%$ of the carboxyl groups are methylated, it is termed HM pectin, and below 50 is classified as LM pectin (Dominiak et al., 2014). DE also determines the type of pectin which is classified by their rate of gel-formation. Two classifications of pectin are rapidset (DE $>72 \%$ ), which can form gels even with little or no sugar, and slow set (DE between 52- 65\%) (Shaha, 2013).

Methoxyl content (MC) is also another indication of the ability of the pectin extracted to form gels. According to Jayani et al. (2005), 75\% of the carboxyl group of good quality pectin are methylated, thus, higher methoxyl conten obtained from the product determines higher ability to form gels, therefore better quality product. Pectin can also be classified based on methoxyl content as low methoxyl pectin (less than $7.0 \%$ ), and high methoxyl pectin (more than $7.0 \%$ ). LM pectins gel in the presence of calcium, whereas $\mathrm{HM}$ pectins gel at low $\mathrm{pH}$ in the presence of high concentrations of a co-solute such as sucrose. High-methoxy pectins are of considerable importance in the food industry since processed fruit products (e.g. jams and jellies) are acidic and contain a high concentration of sucrose (O'Neill et al., 2001). Methoxyl content can also affect the dispersibility of pectin in water where HM is more readily dispersed than LMP. It is generally believed that natural LMP macromolecules within the cell wall result from nascent HMP following the activity of pectin-methyl esterases (Yapo and Koffi, 2014). Thus, formation of LMP can be prevented by prevention of hydrolysis by enzymes or by acid.

Methoxyl contents among fruits obtained were not distinctively different comparing $\mathrm{HCl}$ and enzymatic extractions methods, except in 'Carabao' mango peels. This implies the high methoxyl content of 'Carabao' mango peel pectin compared with the other peels tested. This is also reflected in the DE values obtained with 'Carabao' mango peels. The significant decrease in methoxyl content and DE values of 'Carabao' mango peel pectin is brought about by the harsh conditions of $\mathrm{pH}$ and heat during acid extraction. 'Carabao' mango peel pectin was shown in this study to be a good source of HM pectins. Acid extraction however, could cause decline in pectin quality but enzymatic extraction prevents its demethylation.

\section{Anhydrouronic acid (AUA) content of the extracted pectins}

Anhydrouronic acid (AUA) contents were significantly high for yellow passion fruit peel pectins obtained from cellulase and xylanase extraction (Figure 5). AUA values from 'Saba' banana peel pectins did not vary significantly. For 'Carabao' mango peel pectins, high values were obtained from the enzymatic methods while a significantly lower value was obtained from $\mathrm{HCl}$ extraction Wide variations in AUA values were obtained from soursop 'guyabano' pectins with $\alpha$-amylase having the lowest value.

Anhydrouronic acid content suggests purity of pectins. According to the Food Chemical Codex of 1996, the AUA of pectin should not be more than $65 \%$ to be classified as pure. In Figure 6, pectins from 'Saba' banana and soursop 'guyabano' have high purity, but 'Saba' banana peel pectins have the same levels of purity (33-38\% AUA) regardless of the extraction method. This means that extraction of pectins from 'Saba' banana peels is efficient for both enzymatic and acid extraction due to less contaminants extracted. AUA values for soursop 'guyabano' peels are variable, ranging from 9-56\% depending on the extraction method and enzyme. $\alpha$-amylase produced the lowest AUA value for soursop 'guyabano', which indicates that most contaminants present are in the form of amylose. Thus, the use of $\alpha$-amylase effectively removes most contaminants.

\section{Microstructures of the pectins using Scanning Electron Microscopy (SEM)}

Pectin samples from the different fruit peels extracted using cellulase were viewed under SEM (Figure 7). The pectins extracted from soursop 'guyabano', 'Carabao' mango and yellow passion fruit peels all appeared as rough with corrugations. Soursop 'guyabano' and yellow passion fruit peel pectins appeared to be bulky and has calcified irregular surface. Unlike 'Carabao' mango and 'Saba'banana peel pectins, SEM images showed that they have regular and flat surface. 'Saba' banana peel pectin however, has a smooth surface compared with 'Carabao' mango, which has a slightly corrugated surface.
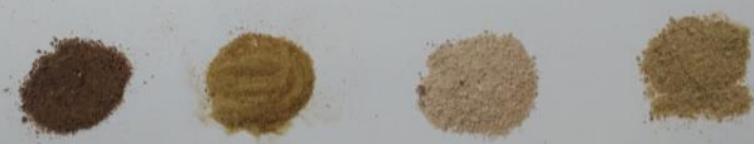

Figure 1 Pectins extracted from various fruit peels (L-R: Soursop 'Guyabano', 'Carabao' mango, 'Saba' banana, Yellow passion fruit) 


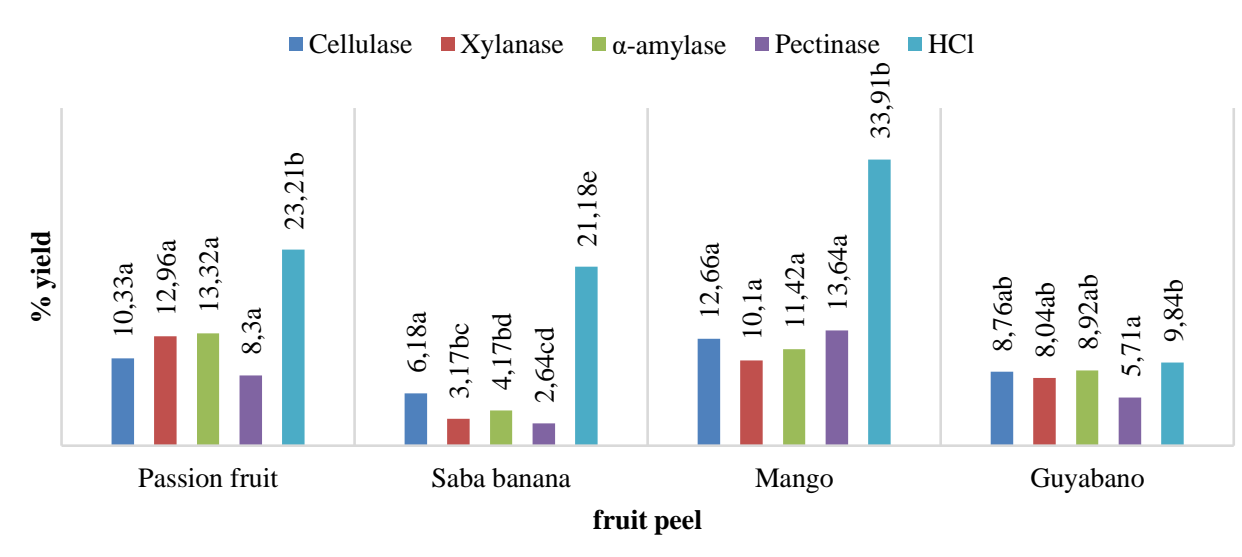

Values with the same letters within a group are not significantly different based on Tukey's HSD Test at $\mathrm{P}=0.05$. Figure 2 Yield of pectin extracted from various fruit peel wastes using microbial enzymes and $\mathrm{HCl}$.

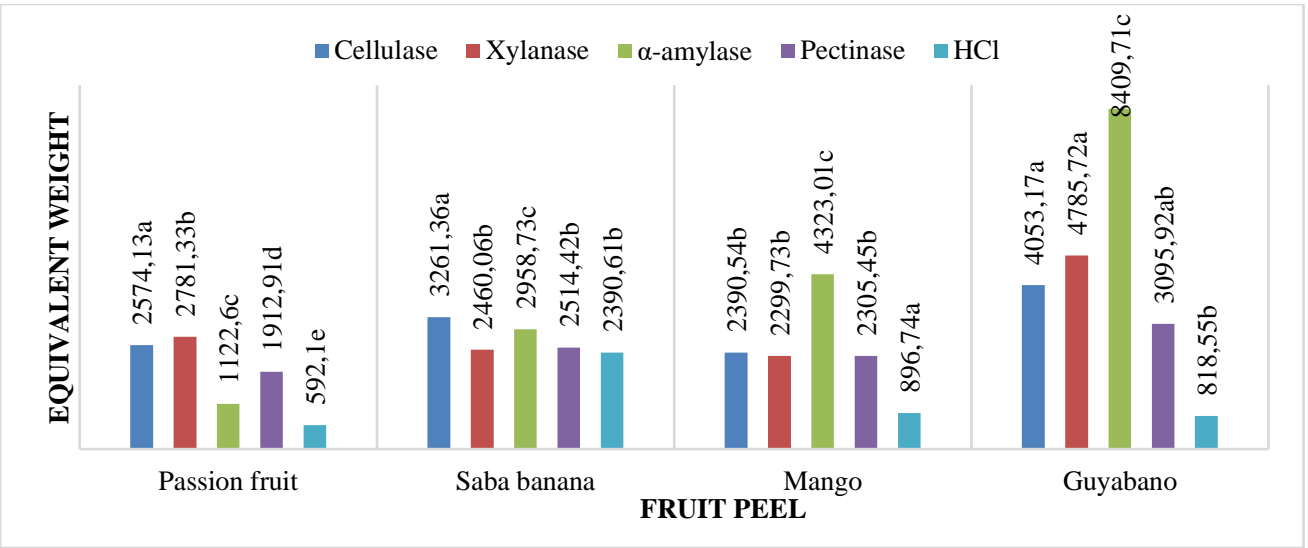

Values with the same letters within a group are not significantly different based on Tukey's HSD Test at $\mathrm{P}=0.05$. Figure 3 Equivalent weight of pectin extracted from various fruit peel wastes using microbial enzymes and $\mathrm{HCl}$.

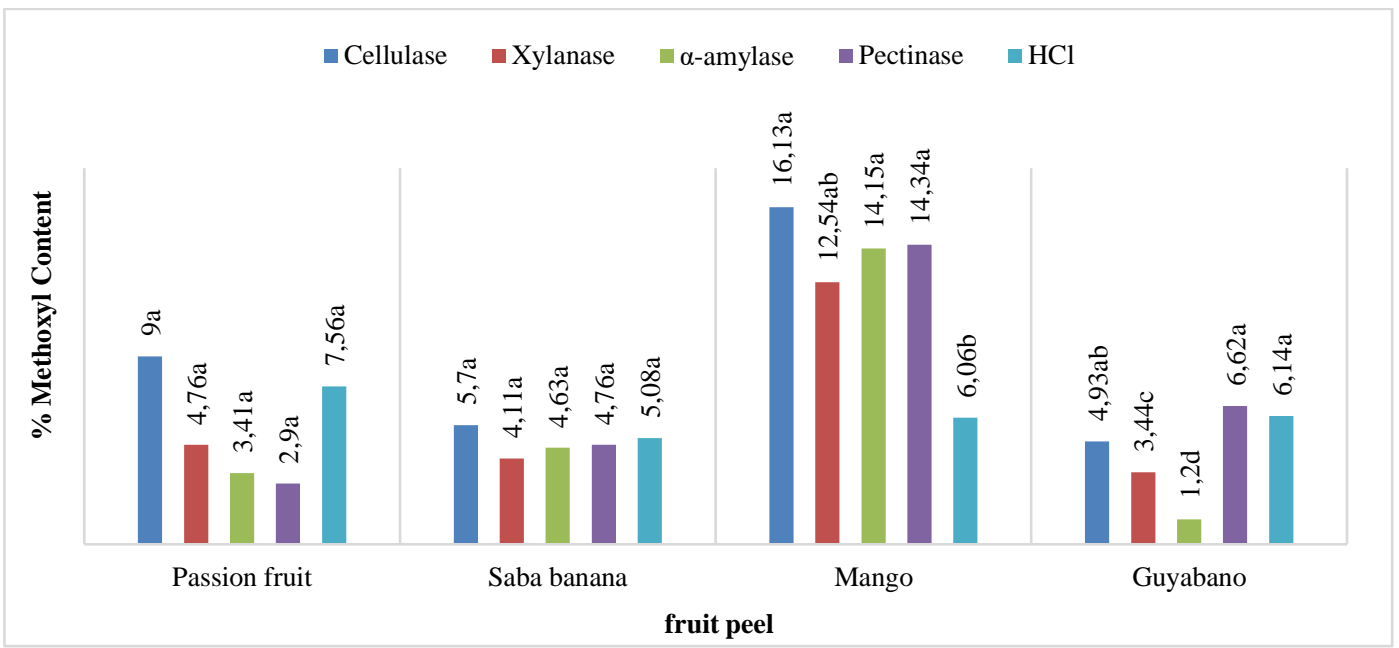

Values with the same letters within a group are not significantly different based on Tukey's HSD Test at $\mathrm{P}=0.05$.

Figure 4 Methoxyl content of pectin extracted from various fruit peel wastes using microbial enzymes and $\mathrm{HCl}$. 


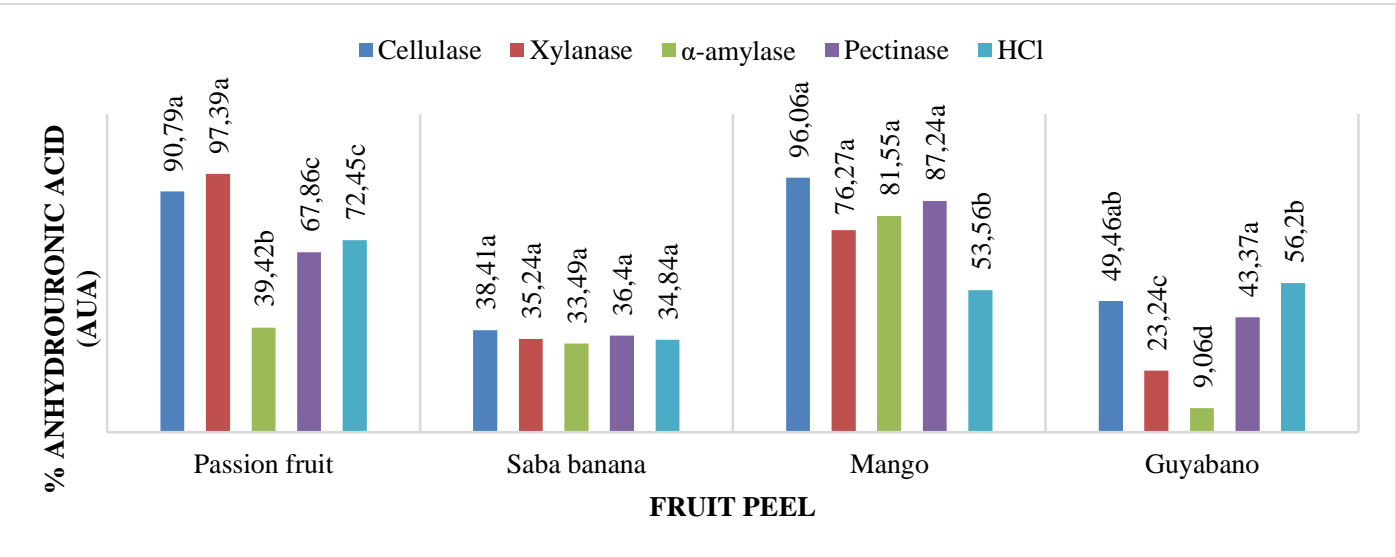

Values with the same letters within a group are not significantly different based on Tukey's HSD Test at $\mathrm{P}=0.05$.

Figure 5 Anhydrouronic acid content of pectin extracted from various fruit peel wastes using microbial enzymes and $\mathrm{HCl}$.

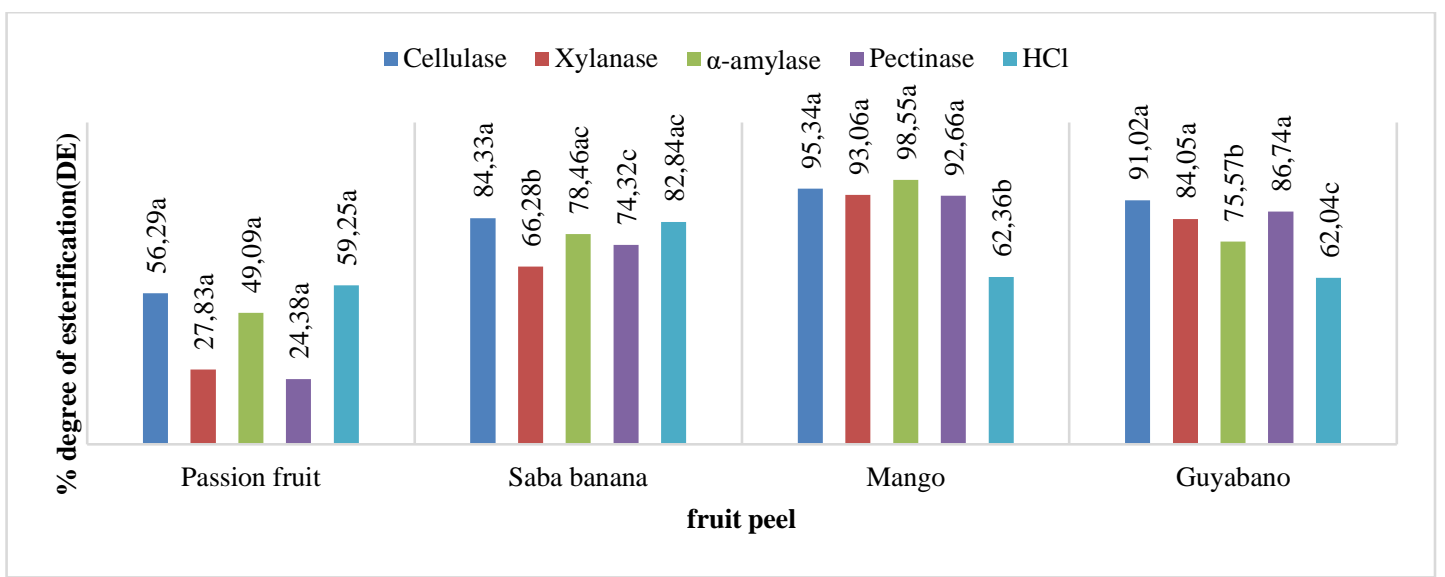

Values with the same letters within a group are not significantly different based on Tukey's HSD Test at $\mathrm{P}=0.05$.

Figure 6 Degree of esterification of pectin extracted from various fruit peel wastes using microbial enzymes and $\mathrm{HCl}$.
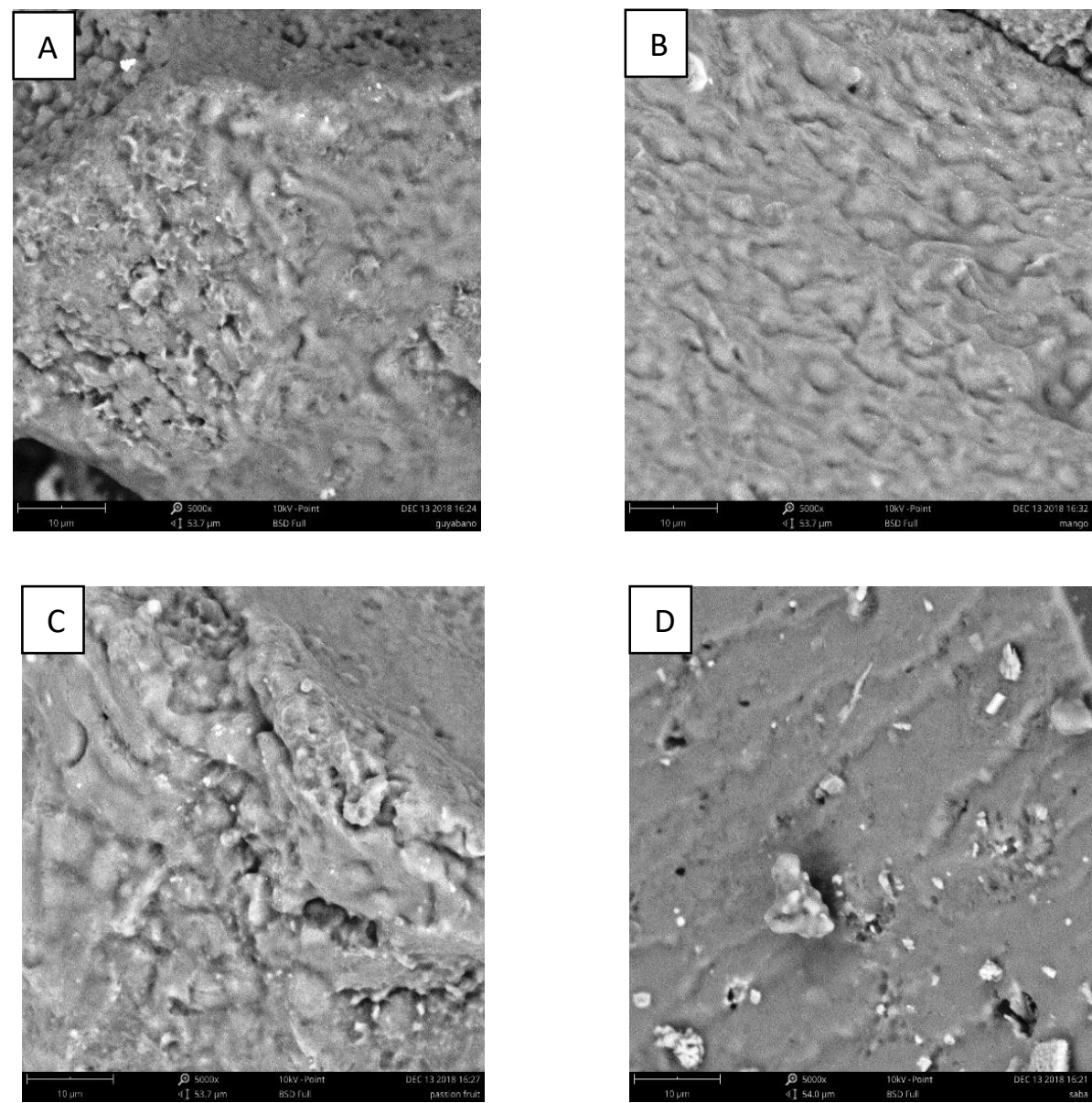

Figure 7. Microstructures of cellulase extracted peel pectins using Scanning Electron Microscopy (SEM) at 5000x magnification. (A- Soursop 'Guyabano', B'Carabao' mango, C- Yellow passion fruit, D- 'Saba' banana) 


\section{CONCLUSION}

In this study, pectin extraction using various microbial enzymes and hydrochloric acid were compared. Cellulase obtained significantly high yield from 'Saba' banana peels as well the highest equivalent weight compared with other enzymes. Low equivalent weights were obtained from acid extraction from all fruit peels compared with enzymatic extraction. This is due to high extent of hydrolysis brought about by the harsh conditions in acid extraction. In general, low yields were obtained from enzymatic extraction. However, better quality was obtained based on methoxyl content and degree of esterification. Among the peels, 'Carabao' mango had the highest methoxyl content. 'Saba' banana and guyabano peels on the other hand, had the highest purity. Overall, enzymatic extraction has shown promising results in extracting pectins from fruit peel wastes and can be considered as an alternative to acid extraction.

Acknowledgments: The authors would like to thank the Enhanced Creative Work and Research Grant (ECWRG) of the University of the Philippines Office of the Vice President for Academic Affairs (OVPAA) for funding this research.

\section{REFERENCES}

CASTILLO-ISRAEL K.A.T., BAGUIO, S.F., DIASANTA, M.D.B., LIZARDO, R.C.M., DIZON, E.I., MEJICO, M.I.F. 2015. Extraction and characterization of pectin from Saba banana [Musa 'saba' (Musa acuminata x Musa balbisiana)] peel wastes: A preliminary study. International Food Research Journal, 22(1): 190-195.

CHEN, H. 2014. Chemical Composition and Structure of Natura Lignocellulose. In: Biotechnology of Lignocellulose. Springer, Dordrecht CONTRERAS-ESQUIVEL, J.C., VOGET, C.E., VITA, C.E., ESPINOZAPEREZ, J.D., RENARD, C.M.G.C., 2006. Enzymatic extraction of lemon pectin by endo-polygalacturonase from Aspergillus niger. Food Sci. Biotechnol., 15: $163-167$.

CUI, S.W. AND CHANG, Y.H. 2014. Emulsifying and structural properties of pectin enzymatically extracted from pumpkin. J. Food Sci., 58:396-403.

DENG, G., SHEN, C., XU, X., KUANG, R., GUO, Y., ZENG, L., GAO, L. LIN, X., XIE, J., XIA, E., LI, S., WU, S., CHEN, F., LING, W., LI., H. 2012. Potential of Fruit Wastes as Natural Resources of Bioactive Compounds. Int. J. Mol. Sci., 13:8308-8323. http://dx.doi.org/10.3390/ijms13078308

DOMINIAK, M., SØNDERGAARD, K. M., WICHMANN, J., VIDALMELGOSA, S., WILLATS, W.G.T., MEYER, A.S., DALGAARD, J.M. 2014 Application of enzymes for efficient extraction, modification, and development of functional properties of lime pectin. Food Hydrocolloids, 40: 273-282 http://dx.doi.org/10.1016/j.foodhyd.2014.03.009

ESPINO, R.R.C. AND ESPINO, M. R. 2015. The Status of the Fruit Industry in the Philippines. Food and Fertilizer Technology Center Extension Bulletin. FFTC Taiwan.

ESPITIA, P.J.P., DU,W. X., JESÚS, A.B., FÁTIMA, R., FERREIRA SOARES, N., MCHUGH, T.H. 2014. Edible films from pectin: Physical-mechanical and antimicrobial properties - a review. Food Hydrocolloids. 35:287-296.

FISSORE, E.N., ROJAS, A.N., GERSCHENSON, L.N., WILLIAMS, P.A. 2013.

Butternut and beetroot pectins: Characterization and functional properties. Food Hydrocolloids. 31: 172-182.

FOOD CHEMICAL CODEX. 1996. IV monographs. Washington DC: National Academy Press. pp 283.

JAYANI, R.S., SAXENA, S., GUPTA, R. 2005. Microbial pectinolytic enzymes: A review. Process Biochemistry, 40: 2931-2944. http://dx.doi.org/10.1016/j.procbio.2005.03.026

JEONG, H.S., KIM, H.Y., AHN, S. H., OH, S. C., YANG, I., CHOI, I.G. 2014. Optimization of enzymatic hydrolysis conditions for extraction of pectin from rapeseed cake (Brassica napus L.) using commercial enzymes. Food Chemistry, 157:332-338.

LIEW, S.Q., CHIN, N.L., YUSOF, Y.A., SOWNHARARAJAN, K. 2015 Comparison of acidic and enzymatic pectin extraction from passion fruit peels and its gel properties. J. Food Process Engr., 39(5): 501-511.

LIM, J., JIYOUNG, YOO, J., KO, S., LEE, S. 2012. Extraction and characterization of pectin from Yuza (Citrus junos) pomace: A comparison of conventional-chemical and combined physical-enzymatic extractions. Food Hydrocolloids, 29: 160-165.

MIN, B., LIM, J., KO, S., LEE, K., LEE, S. H., LEE, S. 2011. Environmentally friendly preparation of pectins from agricultural byproducts and their structural/rheological characterization. Bioresource Technology, 102: 3855-3860. http://dx.doi.org/10.1016/j.biortech.2010.12.019

MUNARIN, F., BOZZINI., S., VISAI, L., TANZI, M.C. , PETRINI, P. 2013. Sterilization treatments on polysaccharides: Effects and side effects on pectin. $\begin{array}{llll}\text { Food Hydrocolloids, } & 31(1): & 74-84\end{array}$ http://dx.doi.org/10.1016/i.foodhyd.2012.09.017

O’NEILL, M.A., DARVILL, A.G., ALBESHIM, P. 2001. Pectic Substances Encyclopedia of Life Sciences pp. 1-11. Nature Publishing Group. www.els.net. OWENS, H.S., MCCREADY, R.M., SHEPHERD, A.D., SCHULTZ, S.H., PIPPEN, E.L., SWENSON, H.A., MIERS, J.C., ERLANDSEN, R.F., MACLAY
W.D. 1952. Methods used at Western Regional Research Laboratory for extraction and analysis of pectic materials. AIC-340, Western Regional Research Laboratory, Albany, California.

PANOUILLE, M., THIBAULT, J. F. AND BONNIN, E. 2006. Cellulase and protease preparations can extract pectins from various plant by-products. J. Agri. Food Chem, 54 (23): 8926-8935.

PTICHKINA, A.N.M., MARKINAA, O.A. AND RUMYANTSEVAB, G.N 2007, Pectin extraction from pumpkin with the aid of microbial enzymes. Food Hydrocolloids, 22 (1) :192-195. http://dx.doi.org/10.1016/i.foodhyd.2007.04.002 QIU, L.P., ZHAO, G.L., WU, H., JIANG, L., LI, X.F., LIU, J.J. 2010 Investigation of combined effects of independent variables on extraction of pectin from banana peel using response surface methodology. Carbohyd. Polym, 80:326-331

RAJ, A. A. S., JAYABAlan, S. R. R., RANGANATHAN, T. V. 2012. A Review on Pectin: Chemistry due to General Properties of Pectin and its Pharmaceutical Uses. Open Access Scientific Reports, Vol 1. Issue 12

ROLIN, C., NIELSEN, B.U., GLAHN, P. E. 1998. Pectin. In Dumitriu, S. (Ed.), Polysaccharides: Structural diversity and functional versatility. New York: Marcel Dekker Inc. pp 377-431.

SEIXAS, F. L., FUKUDA, D. L., TURBIANI, F. R. B., GARCIA, P. S., PETKOWICZ, C. L. DE O., JAGADEVAN, S., GIMENES, M. L. 2014 Extraction of pectin from passion fruit peel (Passiflora edulis f.flavicarpa) by microwave-induced heating. Food Hydrocolloids, 38: 189-192 http://dx.doi.org/10.1016/j.foodhyd.2013.12.001

SHAHA, R.K., NAYAGI, Y., PUNICHELVANA, A., AFANDI, A. 2013. Optimized extraction condition and characterization of pectin from Kaffir lime (Citrus hystrix). Malaysia: Research Journal of Agriculture and Forestry Sciences, 1(2):1-11.

SRIVASTAVA, P. AND MALVIYA, R. 2011. Sources of pectin, extraction and its applications in pharmaceutical industry - An overview. Indian Journal of Natural Products and Resources, 2(1), 10-18.

THAKUR, B. R., SINGH, R. K., HANDA, A. K. , RAO, M. A. 2014. Chemistry and Uses of pectin - A Review. Critical Reviews in Food Science and Nutrition 37:1, 47-73

VACLAVIK, V.A. AND E.W. CHRISTIAN. 2008. Essentials in Food Science. 3rd ed. USA: Springer Science+Business.

VAN BUREN, J.P. 1991. Function of pectin in plant tissue structure and firmness. In The Chemistry and Technology of Pectins (R.H. Walter and S.L. Taylor eds.) pp. 4-10, Academic Press, Inc., California, U.S.A.

YAPO, B.M. 2009. Biochemical Characteristics and Gelling Capacity of Pectin from Yellow Passion Fruit Rind as Affected by Acid Extractant Nature. J. Agric Food Chem., 57 (4), pp 1572-1578. http://dx.doi.org./10.1021/jf802969m

YAPO, B.M. AND KOFFI, K.L. 2014. Extraction and Characterization of Highly Gelling Low Methoxy Pectin from Cashew Apple Pomace. Foods, 3:1-12

YUJAROEN, P., SUPJAROENKUL, U., RUNGRODNIMITCHAI, S. 2008 Extraction of Pectin from Sugar Palm Meat. International Journal of Science and Technology Special Edition, 44-47.

YULIARTI, O., MATIA-MERINO, L., GOH, K. K. T., MAWSON, J.A., BRENNAN, C. S. 2011. Effect of Celluclast 1.5L on the physicochemical characterization of gold kiwifruit pectin. International Journal of Molecular Sciences, 12:6407-6417.

ZYKWINSKA, A., BOIFFARD, M. H., KONTKANEN, H., BUCHERT , J. THIBAULT, J. F., BONNIN, E. 2008. Extraction of green labelled pectins and pectic oligosaccharides from plant byproducts. J. Agric. Food Chem, 56(19) 8926-8935. 